\title{
STUDIES ON THE IMMUNOLOGICAL DIAGNOSIS OF THE ANIMALS SUSPECTED OF RABIES
}

\author{
KiYoshi ANDO, KeIzo ISHII, YUShI OKA AND JyUNKAI IRISAWA \\ (National Institute of Health, Tokyo) \\ KoJI SHIMADA AND TAEMON KATO
}

(Tokyo-To Laboratories for Medical Sciences)

(Received: January 26th, 1953)

\section{INTRODUCTION}

There are two laboratorial measures widely used in the diagnosis of animals suspected of rabies. One is pathological examination of the animal brains, namely, the detection of Negri bodies and the confirmation of the presence of non-purulent encephalitic inflammation and the other is the isolation of causative virus from the same material, especially, the mouse inoculation method reported by Webster and Dawson in 1935 (1). The method to detect the presence of Negri bodies, which is accomplished by staining (Sellers' method) the stamp samples of Ammon's horn, is simple in technique and requires only a short time, so that, it is widely used in practice. It is a well known fact, however, that the detection of Negri bodies is not always positive on the section samples which require a considerable length of time in preparation, not to speak of the stamp samples, in spite of the brains of actually rabid animals are used. There are some strains of street virus which hardly form Negri bodies and when suspicious animals are killed on a relatively early stage of their infection, the formation of Negri bodies may not be complete and sometimes they may be over looked. And further, nervous cell has sometimes so-called "Lyssabody", in which innerformation can not be recognized. The presence of "Lyssabody" is not sufficient for giving the diagnosis of rabies. Especially, when we consider the presence of Negri-like body in the brain of normal mice and cats, it is sometimes difficult to say the detection of Negri bodies only is sufficient for the diagnosis of rabies. Accordingly, it is a matter of great importance to demonstrate the presence of rabies virus by the intracerebral inoculation of small laboratory animals with the brain emulsion of suspicious animal. The method developed by Webster and Dawson(1), which is to use the intracerebral and intraperitoneal inoculation of mice, is much superior in the following points to the one which has hitherto been used employing rabbits or guinea pigs.

1. The technique is much more simple.

2. Larger number of animals are available, and accordingly.

3. Pathological examinations to detect the presence of Negri bodies can be made sacrificing some of the animals under the test on the 4 th, 5 th and 6 th day after inoculation. 
4. The incubation period of street virus in mice is much shorter than that of rabbits or guinea pigs, etc.

However, it takes at least 7 days and sometimes 14 days or longer before the inoculated mice develop symptoms of rabies. Thus, it can be said that this method is important as a confirmatory test for the findings of rapid diagnosis made by staining stamp samples or sections of the brain of suspicious animal, rather than as a method for rapid diagnosis. In addition, the isolation of a certain neurotropic virus from the mice can not serve as a direct proof for the isolation of rabies virus, because the clinical symptoms developed in mice by street virus are not specific to rabies and also it is almost impossible to differentiate them from the encephalitis caused by other neurotropic viruses such as the viruses of Japanese B encephalitis, St. Louis encephalitis, poliomyelitis Lansing type, Russian spring-summer encephalitis etc. The diagnosis will finally be established, therefore, only when the strain isolated is identified immunologically as rabies virus (for this identification mainly neutralization test has hitherto been used.).

Similar thing can be said when performing pathological examinations, namely, when the inclusion bodies are recognized as "Lyssa-bodies" instead of Negri bodies or when only non-purulent encephalitic inflammation is observed histologically, there will be no other means to know whether these lesions are caused by rabies virus or not, except that to rely upon the isolation of the virus and to identify it immunologically as rabies virus. On the other hand, it is an urgent problem to decide whether it is necessary to start vaccination or not on the part of individuals who have received a bite or a scratch by a suspicious rabid animal. Also, regarding so-called conservative injection method, which is applied before the diagnosis of a suspicious animal is established. The vaccination should be discontinued as soon as possible when the diagnosis is negatively established from the standpoint of postvaccinal paralysis which unfortunately may follow this vaccination.

Facing with these practical problems, we felt a strong necessity for rescrutinizing the diagnostic measures presently employed in the diagnosis of suspicious animals which is quite essential in the decision whether or not to apply complete vaccination.

Antigen for complement fixation test was prepared directly from the materials (brain and salivary gland) obtained from the animal suspected of rabies. Complement fixation test was carried out with this antigen and the serum of the guinea pigs immunized with fixed and street rabies viruses in order to detect the presence of antigenic substance specific to rabies. The diagnostic value of this method was compared with those of the laboratorial diagnostic measures hitherto been employed.

In 1907 Heller and Tomarkin(2) and in the same year Friedberger(3) attempted to run complement fixation test using the antigen prepared from 
the brain, salivary gland or other organs of an animal which had developed rabic symptoms and the rabies immune serum in order to establish an immunological diagnosis of the said animal. But this attempt was given up as the test was positive even with the brain of normal rabbit or dog which was used as control. In the year 1910, standing on the findings that the antigens prepared from the salivary gland of $2 \mathrm{dogs}$ died of rabies and that of a man fixed the complement stronger than the control, Nedrigailoff and Sawtschenko (4) stated that this complement fixation test could be utilized for the diagnosis of rabies. In 1926, Kraus and Takaki(5) reported that the complement fixation test made with their kokto antigen, which was prepared from the brain of a rabid rabbit infected with fixed virus and heated at $100^{\circ} \mathrm{C}$ for 30 minutes, and rabies immune serum was positive. But it was proved negative by the follow-up experiments of Marie and Urbain(6) in 1929. Another report on this complement fixation test was published by Kraus and Michalka(7) who employed glycerin extract antigen for the differential diagnosis of rabies and distemper. But Kondo and Obana(8) in 1930 confirmed negative results using the materials obtained from the $\mathrm{dog}$ and rabbit. Those studies, however, were mainly performed with rabbit fixed virus, and the complement fixation reaction produced was not necessarily specific to rabies and the number of cases tested was extremely small. Accordingly, this reaction has not been taken up as a diagnostic measure for the diagnosis of rabies.

\section{Materials and Methods}

The rabies suspected animals employed in the present study were 105 in all obtained from the Tokyo-To Laboratories for Medical Sciences and the brains of 23 stray dogs used as controls, were obtained from the Tokyo-To Central Dog Pound. Suspicious animals brought into the Laboratories alive were sacrificed after examining their clinical symptoms for a certain period, and their brains were harvested aseptically. Sometimes the animals had been killed or had died before they were brought into the said laboratories and on such occasions only their brains were brought in. Ammon's horns of the brain thus obtained were exposed, following the method devised by one of the coauthors, from which stamp samples were prepared for Sellers' modified staining. Separately, the detection of Negri bodies was done by fixing Ammon's horn for 48 hours in anhydrous ethanol, embedding in parafin, cutting into sections and staining by Mann's staining, as well as the medulla oblongata of the same brain material was fixed with anhydrous alcohol for 48 hours, embedded in paraffin, cut into sections and stained by hematoxylin-eosin for the detection of non-purulent encephalitic inflammations (degeneration of nerve cells, proliferation of Glia cells (so-called Babès nodules), perivascular cellular infiltration etc.) 
For animal inoculation test, all the brains and salivary glands (which were used in the latter half of the present study) were prepared into $10 \%$ emulsion with buffered saline $\mathrm{pH}$ 7.6. This emulsion was further diluted into serial ten-fold dilutions of $10^{-1}$ to $10^{-4}$ with $2 \%$ normal horse serum saline, and inoculated intracerebrally into albino mice weighing 8 to $9 \mathrm{~g}$, using a group of 4 to 5 mice for each dilution. The animals inoculated were observed for 2 weeks. When all the mice of one experimental group not succumb to the infection, the brain emulsion of the mice in the group inoculated with the emulsion of $10^{-1}$ dilution was further inoculated into 4 to 5 mice of the next generation, and the observation was continued for additional 3 weeks. The brains of mice which had developed rabic symptoms and those died after developing such symptoms during the observation period were used for the preparation of the antigen. Then, complement fixation test was carried out with this antigen and the serum obtained from the guinea pigs immunized with fixed rabies virus and additionally with street virus, in order to prove immunologically the presence of rabies virus in the brain emulsion.

The above mentioned are the laboratorial diagnostic procedures which have hitherto been used. As mentioned before, however, we have deviced a complement fixation test in which the antigen prepared directly from the materials of the original suspicious animal was used. Comparative evaluations were made in the following between the findings of those laboratorial diagnostic measures which have hitherto been used and the findings of newly deviced complement fixation test.

\section{Preparation of the antigen:}

Brain: The brains of dog killed under the suspicion of rabies were used as soon as harvested, but sometimes, they were stored in a deep freezer after removing the materials required for pathological examinations. No particular selection was made as to the part of the brain to be used. However, since Ammon's horn was used for the detection of Negri bodies and the medulla oblongata for non-purulent encephalitic inflammation, the part used was mainly the cortical portion of the brain. Approximately $5 \mathrm{~g}$ of the brain tissue was weighed out aseptically and physiological saline solution at $\mathrm{pH} 7.2$ was added to it in such a quantity as would make a brain emulsion of $40 \%$ by weight, namely $7.5 \mathrm{ml}$ of saline solution was added to $5 \mathrm{~g}$ of the brain tissue. The brain tissue was emulsified in a mortar with the help of sterile sand, or by Waring blendor. This emulsion was dispensed into hard glass test tubes of medium size, and immersed in $40^{\circ} \mathrm{C}$ waterbath for 1 hour and centrifuged at $10,000 \mathrm{rpm}$ for 15 minutes. The supernatant fluid thus obtained was used as the antigen. Formerly, we followed the original method of Casals et al.(9), namely, the brain emulsion was first left overnight in a refrigerator for elution, centrifuged at $3,000 \mathrm{rpm}$ for 30 minutes on the next day and the supernatant fluid was frozen and thawed repeating for 5 times and then centrifuged. At present, 
however, in order to economize time and labor, the above mentioned method has been used in our laboratory (Table 1). Several experiments in an early stage of the present study were carried out with the antigen prepared by acetone-ether treatment which had been used by Casals et al.(10) for the study on the complement fixation test of poliomyelitis virus Lansing type $\mathrm{MEF}_{1}$ strain. The use of this method, however, was discontinued because the procedures were too much complicated, purification of market acetone and ether was necessary before they were used, and also, by some unknown cause, the antigen prepared from the dog brain by this method was found sometimes even stronger in the anticomplementary action than the antigen prepared by physiological saline treatment. So that, the brain antigen used in our complement fixation tests was so-called crude antigen prepared by the method mentioned in the above.

Table 1. Antigenicity comparison of antigens prepared by differented methods of elution

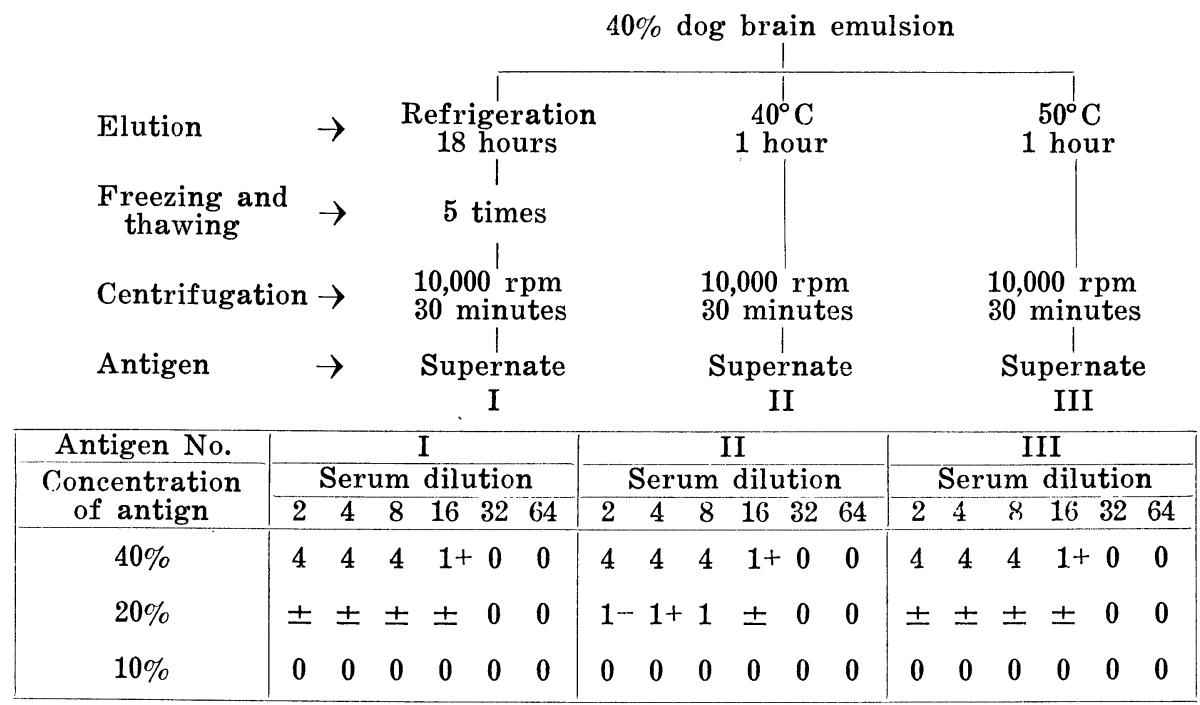

Salivary gland: The salivary glands used were mainly submaxillary glands. Aseptically harvested salivary gland was first removed of its peripheral fat, and the capsule of the gland was removed with the help of scissors and pincette. Then, it was weighed and cut into pieces as small as about $1 \mathrm{~mm}^{3}$. Adding physiological saline $(\mathrm{pH}$ 7.2) in an amount twice as much the wet weight of the gland ( $6 \mathrm{ml}$ of saline per $3 \mathrm{~g}$ of the gland), the gland was emulsified in a Waring blendor for 5 to 10 seconds. Then, as mentioned under the preparation of brain antigen, this emulsion which still had coarse particles of the salivary gland tissue was dispensed into hard glass test tubes of medium size. After extracting at $40^{\circ} \mathrm{C}$ for 1 hour, the emulsion was centrifuged at $10,000 \mathrm{rpm}$ for 15 minutes. The supernatant obtained was used as the antigen for complement fixation test. The grinding of salivary gland appears to be insufficient 
and the amount of saline used looks rather too much (brain is made into $40 \%$ emulsion and salivary gland is $33 \%$ ). But when grinding for a longer period in the case of salivary gland, effusion of the gland will not be obtained because of the mucin of the gland itself.

2. Immune serum: The diagnostic rabies immune serum used in the complement fixation test was guinea pig immune serum. As the antigen for immunization, the brain tissues of homologous animal, namely, the brains of those guinea pigs infected and developed symptoms of rabies were used in order to avoid the production of normal brain tissue antibodies. It has already been pointed out(11) that the normal guinea pigs in Japan occasionally have, especially during the summer season, the complement fixing antibody for the virus of Japanese B encephalitis. All the guinea pigs used, therefore, had been confirmed of the absence of antibody in their sera against the virus of Japanese $B$ encephalitis before they were used for this immunization. In other words, it is essential that rabies diagnostic serum must absolutely be free from any antibodies other than that of rabies virus. More than 10 guinea pigs thus selected, weighing approximately $350 \mathrm{~g}$, were immunized intraperitoneally with $2.0 \mathrm{ml}$ of $10 \%$ ultraviolet inactivated vaccine prepared from the fixed virus $\mathrm{MDH}$ strain. Again they were immunized with the same vaccine in the same dose. As it was more desirable to use the emulsions prepared from many strains of rabies virus for this kind of diagnostic purpose, the booster inoculations with the virus emulsions prepared from newly isolated street viruses were applied on those animals. Table 2 is an example of such immunization and Table 3 is the results of the complement fixation tests done by using the rabies immune serum thus obtained and the rabies virus or other neurotropic viruses.

3. Complement: The bleeding was done from 10 to 15 normal guinea pigs and their blood was mixed after confirmation of the absence of complement fixing antibody for Japanese $B$ encephalitis virus.

Table 2. Preparation of rabies immune serum (guinea pig)

\begin{tabular}{|c|c|c|c|}
\hline Times & $\begin{array}{l}\text { Date of } \\
\text { injection }\end{array}$ & Procedures of immunization & $\begin{array}{r}\text { Date of } \\
\text { bleeding }\end{array}$ \\
\hline 1 & 18/IX & $\begin{array}{l}\text { Intraperitoneal injection with } 2 \mathrm{ml} \text { of } 10 \% \text { ultra- } \\
\text { violet irradiated vaccine (MDH strain) }\end{array}$ & \\
\hline 2 & $25 / \mathrm{IX}$ & ; & \\
\hline 3 & $2 \mathrm{X}$ & $\begin{array}{l}\text { Intraperitoneal injection with } 2 \mathrm{ml} \text { of } 10 \% \text { ultra- } \\
\text { violet irradiated vaccine (Terashima strain) }\end{array}$ & \\
\hline 4 & $9 / \mathrm{X}$ & $\begin{array}{l}\text { Intraperitoneal injection with } 2 \mathrm{ml} \text { of } 10 \% \text { brain } \\
\text { emulsion of the guinea pig infected with street virus }\end{array}$ & \\
\hline 5 & $14: \mathrm{X}$ & (Strain No. 162, 163) & $24: \mathrm{X}$ \\
\hline 6 & $27 / \mathrm{X}$ & (Strain No. 170) & \\
\hline 7 & $4 / \mathrm{XI}$ & (Strain No. 174, 175) & $8 / \mathrm{XI}$ \\
\hline 8 & $13 ; \mathrm{XI}$ & (Strain No. 164) & $18 / \mathrm{XI}$ \\
\hline
\end{tabular}

10 Guinea pigs used were weighing approximately $350 \mathrm{~g}$ 
Table 3. Specificity of rabies immune serum

\begin{tabular}{|c|c|c|c|c|c|c|c|c|c|}
\hline \multirow{2}{*}{$\underset{\text { serum }}{\text { Immume }}$} & \multirow{2}{*}{ Antigen } & \multicolumn{6}{|c|}{ Serum dilution } & \multicolumn{2}{|c|}{ Controls } \\
\hline & & 2 & 4 & 8 & 16 & 32 & 64128 & Antigen & Serum \\
\hline \multirow{6}{*}{$\begin{array}{l}\text { Guinea } \\
\text { pigs rabies } \\
\text { immune } \\
\text { serum }\end{array}$} & Rabies (MDH strain) & 4 & 4 & 4 & 4 & 4 & \pm 0 & 0 & 0 \\
\hline & Japanese B encephalitis & 0 & 0 & 0 & 0 & 0 & & 0 & \\
\hline & St. Louis encephalitis & 0 & 0 & 0 & 0 & 0 & & 0 & \\
\hline & Negishi Strain & 0 & 0 & 0 & 0 & 0 & & 0 & \\
\hline & $\begin{array}{l}\text { Russian spring-summer } \\
\text { encephalitis (western) }\end{array}$ & 0 & 0 & 0 & 0 & 0 & & 0 & \\
\hline & Normal dog brain & 0 & & & & & & 0 & \\
\hline
\end{tabular}

4. Hemolytic system: An amount of blood cell suspension in a concentration of $3 \%$ which was prepared from defibrinated sheep blood was mixed with an equal amount of 3 unit sheep blood hemolysin solution.

5. Medium for the complement fixation test: Ordinary physiological saline of $\mathrm{pH} 7.2$ has been used in numerous cases of complement fixation tests for the neurotropic viruses such as Japanese B encephalitis, rabies and poliomyelitis viruses. No inconvenience has been encountered by the use of this medium so far as mouse, guinea pig or hamster is used as the animal for antigen preparation. A slight anticomplementary influence was noted, however, in the control tube of the antigen prepared from the cotton rat which had been inoculated intraspinally with the virus of poliomyelitis Lansing type. Of course, it was anticipated that there might be a possibility of such anticomplementary activity depending on the species of animal used in the preparation of antigen. When preparing antigen from the brains of animals suspected of rabies infection, therefore, particular care was taken on the fact that the brains used were mostly dog brains. Thus, the presence of a slight anticomplementary activity was noted among the tubes of brain antigen controls of stray dogs which contained no immune serum, while those tubes containing a sufficient amount of the serum showed perfect hemolysis. When the serum of normal guinea pig or horse was added, however, to a concentration of 25-50\% in the place of physiological saline which was used ordinarily as medium in the reaction system, the occurrence of non-specific reaction which was considered to be caused by the deficiency of serum protein, was mostly eliminated (Table $6)$.

In our experiment, the medium added with normal guinea pig serum to a concentration of $50 \%$ was used for dilution. The guinea pig serum was inactivated by heating at $60^{\circ} \mathrm{C}$ for 20 minutes and after confirmation of its freedom from the antibodies against the viruses of Japanese $B$ encephalitis, rabies etc., it was used as a 50\% serum saline solution. In the main complement fixation test, the mixture of an equal amount of medium (50\% serum. 
saline) and immune serum was set aside in order to confirm that this mixture did not combine the complement (Table 5).

6. Techniques of the complement fixation test: The method reported by Casals and Palacios (9) in 1941 was used in an early part of the present study. However, the total quantity of the materials used in the test was reduced to $3 / 5(0.9 \mathrm{ml})$ of the original method $(1.5 \mathrm{ml})$ as the antigen used was highly concentrated. As it was very essential to know the result in relatively short period of time, various attempts were made to shorten the period required for the reaction, and it was found that the findings of the reactions performed at $37^{\circ} \mathrm{C}$ for 2 hours were comparable with those of the reactions performed at $4-8^{\circ} \mathrm{C}$ for 18 hours used hitherto (Table 4 ). In either of the above two methods, the complement used was 2 units. Though the complement fixation test performed at $37^{\circ} \mathrm{C}$ for 2 hours was slightly inferior to the one carried out at a low temperature for a longer period of time, the former method was used in the latter half of the study, for it was better in avoiding non-specific reactions as well as it enabled to shorten more than 10 hours the period required for knowing the result. The details of the procedures of complement fixation test are shown in Table 5.

Table 4. Comparison of different incubations

\begin{tabular}{|c|c|c|c|c|c|c|c|c|c|c|}
\hline $\begin{array}{l}\text { method of } \\
\text { incubation }\end{array}$ & \multicolumn{5}{|c|}{$37^{\circ} \mathrm{C} \quad 2$ hours } & \multicolumn{5}{|c|}{$4 \sim 8^{\circ} \mathrm{C} \quad 18$ hours } \\
\hline \multirow{2}{*}{$\begin{array}{l}\text { Concentration } \\
\text { of antigen }\end{array}$} & \multicolumn{5}{|c|}{ Serum dilution } & \multicolumn{5}{|c|}{ Serum dilution } \\
\hline & 4 & 8 & 16 & 32 & 64 & 4 & 8 & 16 & 32 & 64 \\
\hline $10 \%$ & & 4 & 4 & 0 & 0 & & 4 & $3+$ & 0 & 0 \\
\hline $5 \%$ & 4 & 4 & $2-$ & 0 & 0 & 4 & 4 & $3-$ & 0 & 0 \\
\hline $2.5 \%$ & 4 & 2 & 1 & 0 & 0 & 4 & 4 & $1-$ & 0 & 0 \\
\hline $1.25 \%$ & 1 & $1-$ & \pm & 0 & 0 & 4 & 2 & \pm & 0 & 0 \\
\hline $0.63 \%$ & 0 & 0 & 0 & 0 & 0 & $3-$ & 1 & 0 & 0 & 0 \\
\hline
\end{tabular}

\section{RESULTS}

Complement fixation tests made with the brain tissues of suspicious and normal animals.

The results of investigations made on the brains of 105 animals suspected of rabies and 23 stray dogs which appeared quite normal are shown in Tables 6 and 7.

It is a matter of great significance that the reactions of normal brains of 23 stray dogs, as mentioned above, were all negative except those extremely slight non-specific reactions which, it is considered to be due to the influence of normal brain tissue in the reaction system of poor protein content, and that the findings of the suspicious animals were mostly in conformance with the respective findings of viral isolation though the number examined was yet small (Tables 6 and 7). Out of all cases examined, No. 166, in which the antigen treated with acetone-ether was used, showed a strong anti-complemen- 
Table 5. Techniques of complement fixation test

Estimation of the amount of complement used

\begin{tabular}{|l|cccccc|c|}
\hline \multicolumn{1}{|c|}{ Test tube No. } & 1 & 2 & 3 & 4 & 5 & 6 & Control \\
\hline Complement (1:30) & $0.08_{\mathrm{ml}}$ & 0.09 & 0.10 & 0.11 & 0.12 & 0.13 & - \\
Physiological saline solution & 0.52 & 0.51 & 0.50 & 0.49 & 0.48 & 0.47 & 0.6 \\
Hemolytic system & 0.3 & 0.3 & 0.3 & 0.3 & 0.3 & 0.3 & 0.3 \\
\hline \multicolumn{7}{|c}{$37^{\circ} \mathrm{C}$} & 30 minutes \\
\hline Reading & $1-$ & \pm & 0 & 0 & 0 & 0 & 4 \\
\hline
\end{tabular}

Main test

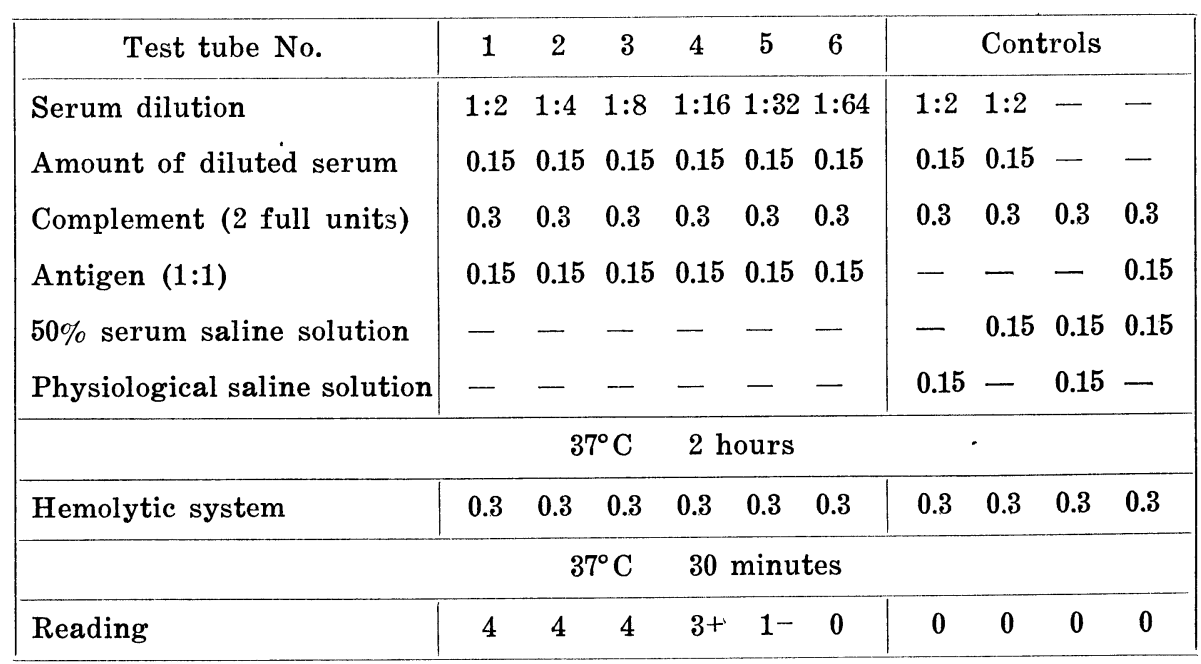

For serum dilution, 50\% guinea pig or horse serum saline solution was used. Confirmed of negative complement fixation reaction between the serum used and the normal brain antigen.

Re-examination of the complement used

\begin{tabular}{|l|rrr|c|}
\hline Test tube No. & 1 & 2 & 3 & Control \\
\hline Complement (2 full units) & 0.1 & 0.15 & 0.2 & - \\
Physiological saline solution & 0.5 & 0.45 & 0.4 & 0.6 \\
\hline & $37^{\circ} \mathrm{C}$ & 2 hours & \\
\hline Hemolytic system & 0.3 & 0.3 & 0.3 & 0.3 \\
\hline & $37^{\circ} \mathrm{C}$ & 30 minutes & \\
\hline Reading & $1+$ & 0 & 0 & 4 \\
\hline
\end{tabular}


$A N D O$ et al

Table 6. Complement fixation test and mouse inoculation test of normal dog brains

\begin{tabular}{|c|c|c|c|c|c|c|c|c|c|c|c|}
\hline \multirow{3}{*}{$\begin{array}{c}\text { Animal } \\
\text { No. }\end{array}$} & \multicolumn{9}{|c|}{ Complement fixation test } & \multirow{3}{*}{$\begin{array}{c}\text { Animal } \\
\text { experi- } \\
\text { ment }\end{array}$} & \multirow{3}{*}{ Remarks } \\
\hline & \multicolumn{6}{|c|}{ Serum dilution } & \multirow{2}{*}{$\begin{array}{l}\text { Anti- } \\
\text { gen } \\
\text { control }\end{array}$} & \multirow{2}{*}{$\begin{array}{c}\text { Kind of } \\
\text { anti- } \\
\text { gens }\end{array} \mid$} & \multirow{2}{*}{$\begin{array}{l}\text { Anti- } \\
\text { body } \\
\text { titer }\end{array}$} & & \\
\hline & 2 & 4 & 8 & 16 & 32 & & & & & & \\
\hline N 1 & 0 & 0 & 0 & 0 & 0 & & $1-$ & A.E. & \multirow{6}{*}{$1: 32$} & $0 / 4$ & $\begin{array}{l}\text { Serum was diluted } \\
\text { with physiological sa- } \\
\text { line solution }\end{array}$ \\
\hline $\mathrm{N} 2$ & 0 & 0 & 0 & 0 & 0 & & $\mathbf{0}$ & ” & & $0 / 4$ & $"$ \\
\hline N 3 & 0 & 0 & 0 & 0 & 0 & & \pm & " & & 0,3 & ” \\
\hline N 4 & 0 & 0 & 0 & 0 & 0 & & \pm & ” & & $0 / 4$ & " \\
\hline \multirow[b]{2}{*}{ N 5} & 0 & 0 & 0 & 0 & \pm & & 1 & ” & & & " \\
\hline & 0 & 0 & 0 & 0 & & 0 & 0 & " & & $0 / 5$ & $\begin{array}{l}\text { Serum was diluted } \\
\text { with } 50 \% \text { normal guin- } \\
\text { ea pig serum saline } \\
\text { solution }\end{array}$ \\
\hline $\mathrm{N} 41$ & 0 & 0 & $\mathbf{0}$ & 0 & 0 & & 0 & Crude & \multirow{9}{*}{$1: 32$} & $0 / 4$ & " \\
\hline $\mathrm{N} 42$ & 0 & 0 & 0 & 0 & 0 & 0 & 0 & " & & $0 / 5$ & $"$ \\
\hline N44 & 0 & 0 & 0 & 0 & 0 & 0 & 0 & " & & $0 / 4$ & " \\
\hline N45 & 0 & 0 & 0 & 0 & 0 & 0 & 0 & " & & $0 / 3$ & " \\
\hline N46 & 0 & 0 & 0 & 0 & 0 & 0 & 0 & " & & $0 / 3$ & " \\
\hline N47 & 0 & 0 & 0 & 0 & 0 & 0 & 0 & $"$ & & $0 / 4$ & " \\
\hline N48 & 0 & 0 & 0 & 0 & 0 & 0 & 0 & " & & $0 / 4$ & " \\
\hline N49 & 0 & 0 & 0 & 0 & 0 & 0 & 0 & " & & $0 / 4$ & " \\
\hline N50 & 0 & 0 & 0 & 0 & 0 & 0 & 0 & " & & $0 / 4$ & " \\
\hline N51 & 0 & 0 & 0 & 0 & 0 & 0 & 0 & " & \multirow{9}{*}{$1: 16$} & $0 / 5$ & \begin{tabular}{|lll} 
Serum was & diluted \\
with $50 \%$ & normal \\
horse serum & saline \\
solution &
\end{tabular} \\
\hline N52 & 0 & 0 & 0 & 0 & 0 & 0 & 0 & $"$ & & $0 / 5$ & " \\
\hline N53 & 0 & 0 & 0 & 0 & 0 & 0 & 0 & " & & $0 / 5$ & " \\
\hline N54 & 0 & 0 & 0 & 0 & 0 & 0 & 0 & " & & $0 / 5$ & " \\
\hline N55 & 0 & 0 & 0 & 0 & 0 & 0 & 0 & $"$ & & $0 / 4$ & " \\
\hline N56 & 0 & 0 & 0 & 0 & 0 & 0 & 0 & " & & $0 / 5$ & " \\
\hline N57 & 0 & 0 & 0 & 0 & 0 & 0 & 0 & $"$ & & $0 / 4$ & $"$ \\
\hline N59 & 0 & 0 & 0 & 0 & 0 & 0 & 0 & " & & 0,5 & " \\
\hline N60 & 0 & 0 & 0 & 0 & 0 & 0 & 0 & " & & 0,5 & $"$ \\
\hline
\end{tabular}

A.E. …. Antigens treated with acetone and ether.

Crude …... Antigens frozen and thawed.

Animal experiment ….. Denominators indicate the number of mice inoculated and numerators the number of mice died.

Observation period: 4 weeks, 


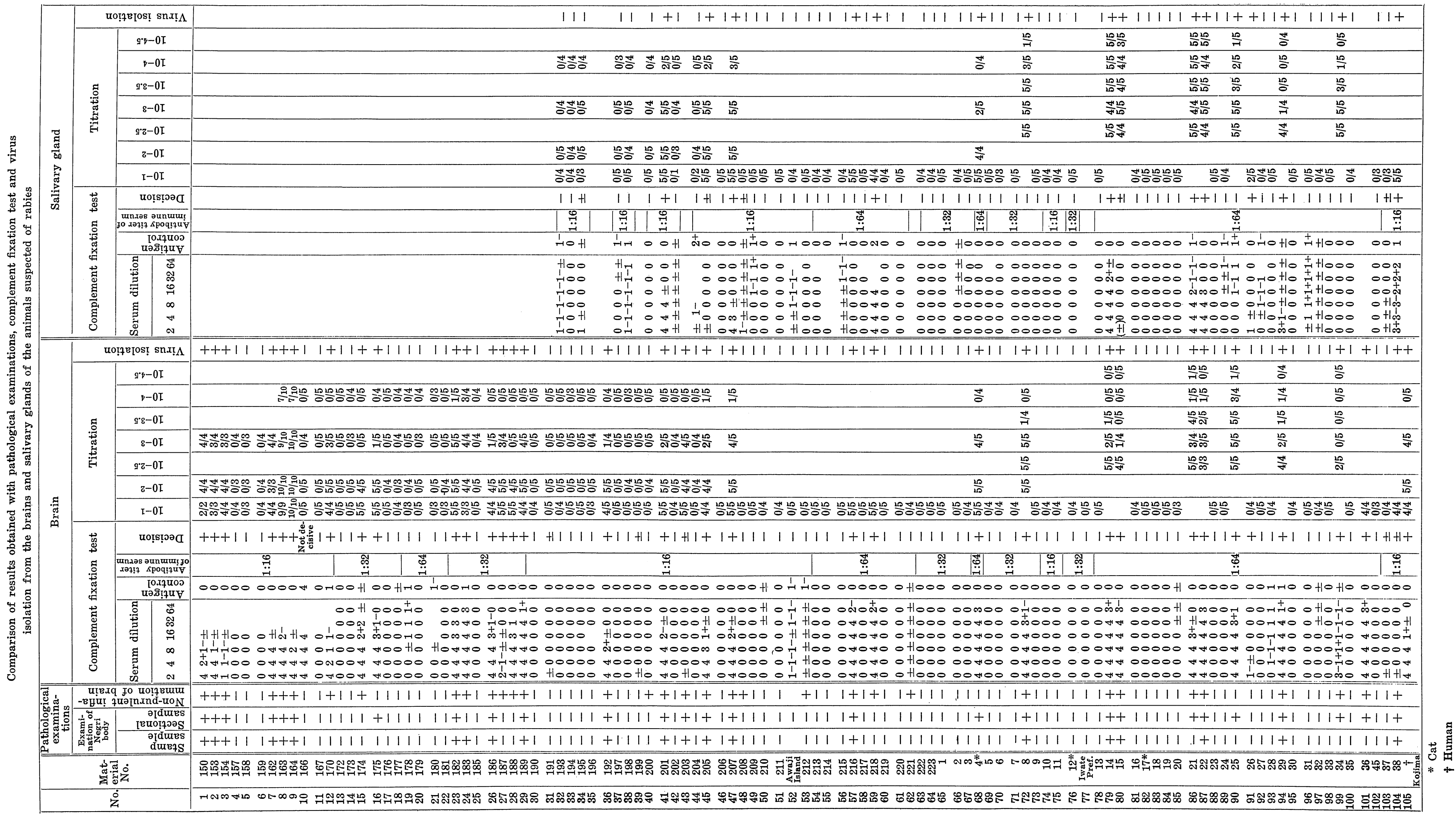


tary influence despite freshness of the brain used in antigen preparation. However, this is considered to be due to the erroneous manipulation when preparing the antigen. No. 191, No. 199 and No. 37, though they showed weak positive reactions in the complement fixation test, the viral isolations were negative (Table 7). Except those four cases mentioned above, the findings of complement fixation test which were known in such an early stage of 5 hours after starting the test, were in conformance with the findings of animal experiment which were known 4-5 weeks later. But what must be emphasized is the reading of the results of complement fixation test. In the complement fixation test for detecting the presence of the antibodies in the serum of Japanese $B$ encephalitis or other viral infections, the highest serum dilution of $50 \%$ hemolysis which is designated by " 2 ", has been taken as the antibody titer of the serum. But in the present experiment, in order to detect an extremely small quantity of the antigen contained in an unknown brain material by using the immune serum of definite potency, it was indispensable to detect even the residual blood cells in the first tube.

The pathological diagnosis of rabies, which is to detect the presence of Negri body by Sellers' staining or its modification applied on the stamp sample of Ammon's horn is very efficient and useful, as it is easily done in any laboratory within a relatively short period of time if examined by experienced person. 'As mentioned before, however, the detectivity is not always $100 \%$ depending on the time of the harvest of the brain or on the strain of street virus and sometimes a structure very much resembled to that of Negri body will be formed in the brain of dog suffering from distemper which is very difficult to differentiate from Negri body. It is not sufficient, therefore, to rely upon the detection by staining sample only when giving diagnosis of rabies.

In addition, the method to detect the presence of Negri body by preparing section is much better than the stamp sample method though in requires over 72 hours before microscopical examination, but even with this method the negative confirmation of the rabies infection is impossible. Regarding the detection of non-purulent encephalitic pictures in the hematoxylin-eosin stained section samples of mesencephalon, brain-stem and medulla oblongata, since the nonpurulent encephalitic pictures are not the specific inflammation to rabies, the diagnosis can only be established when the virus isolated from the experimental animal is immunologically identified as rabies virus for which a considerable length of time is required. In the animal inoculation test which paralleled the complement fixation test, observation of the mice inoculated with the test material was made for a period of 2 weeks. Out of mice which presented no symptoms during this observation period, those inoculated with the brain emulsion of the lowest dilution $\left(10^{-1}\right)$ were sacrificed and their brain emulsion was inoculated intracerebrally into the mice of the second generation and observed for additional 3 weeks. It should be emphasised that a method which is 
considered to have much higher detectivity than Webster's original method was used in the present experiment.

Complement fixation test made with the salivary glands of suspicious animals:

In the early stage of the present experiment, the complement fixation test was done mainly with the brain emulsions of suspicious animals, but the same test with salivary gland and virus isolation from the same material were started from the middle of the experiment. The findings of the tests made with salivary glands are shown in Table 7.

Preparation of the salivary gland antigen was done by cutting the gland with scissors as small as about $1 \mathrm{~mm}^{3}$ and physiological saline in an amount twice as much of the wet weight of the gland was added to it and then emulsified by Waring blendor for 5 to 10 seconds. After extracting at $40^{\circ} \mathrm{C}$ for 1 hour, the emulsion was centrifuged at 10,000rpm for 15 minutes. Therefore, the dilution of salivary gland emulsion $(33 \%)$ was slight higher than that of the brain $(40 \%)$. Generally speaking, a slight anti-complementary influence was observed rather frequently which might be due to the fact that the removal of fat and connective tissue was not complete. However, this gave no difficulty in reading the results. Namely, virus strains identified as rabies virus were isolated from all the cases which had been positive in the complement fixation test made with salivary gland.

After carrying out many complement fixation tests made with salivary glands, however, it was found that there were a considerable numbers of cases in which the virus isolation was positive and the complement fixation test was negative, so that the negative findings of the complement fixation tests made with salivary glands did not mean the absence of rabies virus in the saliva (Table 7). In other words, the virus isolation from the salivary gland is always positive, when the complement fixation test made with the brain antigen is positive. Thus, the disposition of prophylactic treatment must be based on the finding of the complement fixation test made with the brain antigen and not on the finding of the test made with the salivary antigen. As shown in Table 7, the comparison of virulence between the virus recovered from the brain and that from the salivary gland in each animal revealed that the virulence of salivary gland is even higher than that of the brain. Discussion will be made later on the reason why the antigenicity of this salivary gland which is found with even higher virulence is lower than that of the brain tissue.

Experimental evaluation of the findings:

The examinations of above mentioned 105 cases of suspicious animals were carried out by two different groups of investigators. One group engaged in the complement fixation test, isolation of the virus and its immunological identification, while the other group engaged in the detection of Negri body by the stamp samples or the section samples of Ammon's horn, the detection of the 
non-purulent encephalitic inflammation by the section samples and also the detection of Negri body in the brain of the inoculated animal. The examinations in those two groups were carried out independently and the results obtained agreed well (Table 7). However, the following experiments were carried out in order to confirm the diagnostic value of our immunological examination method.

Guinea pigs weighing approximately $350 \mathrm{~g}$ were inoculated into the sole of the left hind leg with the street virus strain No. 163 each in a dose of $0.1 \mathrm{ml}$ of 1:10 mouse brain emulsion, which was obtained from the mice in the first generation of the virus isolated from the dog brain. The observation period was 3 weeks and those guinea pigs which showed no symptoms during this period were sacrificed by bleeding. Their brains were removed aseptically and made into an emulsion of $40 \%$ following the method described above. The emulsion thus prepared was used for the complement fixation test as well as for the titration of the virus which was done by the intracerebral inoculation of mice weighing 8 to $9 \mathrm{~g}$ (Table 8 ). Likewise, the street virus strain No. 182 was inoculated intracerebrally into the guinea pigs weighing approximately $350 \mathrm{~g}$ each in a dose of $0.1 \mathrm{ml}$ of $1: 10$ dilution of the mouse brain emulsion. Two guinea pigs selected at random were sacrificed every day by bleeding for running the complement fixation test and the virus titration (Tables 9 and 10). This experiment was repeated twice. The results obtained are summarized in the Tables 8 to 10 .

Among the guinea pigs inoculated with $0.1 \mathrm{ml}$ of the $10 \%$ brain emulsion of the street virus strain No. 163 into the sole and sacrificed 3 weeks after inoculation, the virus was proved present in the animals of G6 and G8 though the concentration was relatively low. Whereas, all the complement fixation tests done with the same material were negative and the detection of Negri body as well as non-purulent encephalitic inflammation were also negative (Table 8). Thus, together with those findings obtained from the intracerebral inoculation tests on mice carried out at the same time, it is quite evident that the multiplication of the virus to a certain extent is indispensable before the complement fixation reaction becomes positive (Tables 8 to 10 ).

When the findings of our immunological method used in the diagnosis of suspicious animals are taken into consideration, the facts that the guinea pigs inoculated into the sole developed no symptom even by the end of the 3rd week (Table 8), and that out of those guinea pigs inoculated intracerebrally, only one developed slight symptoms as late as on the 6th day (Table 10) are very interesting. Namely, it is quite reasonable to have some cases which are negative in the complement fixation test but positive in the detection of virus with extremely low titer on the same brain material. However, there was not even a case of such occurrence though the number of the cases examined was not sufficient for making any decisive conclusions. As to the reason why, 
$\dot{A N D O}$ et al

Table 8. Comparison of virus concentration and antigenicity of the brains of guinea pigs experimentally infected with rabies I

\begin{tabular}{|c|c|c|c|c|c|c|c|c|c|c|c|c|}
\hline \multirow{3}{*}{$\begin{array}{c}\text { Animal } \\
\text { No. }\end{array}$} & \multirow{3}{*}{$\begin{array}{l}\text { Patholo- } \\
\text { gical ex- } \\
\text { amination }\end{array}$} & \multicolumn{8}{|c|}{ Complement fixation test } & \multicolumn{2}{|c|}{ Titration } & \multirow{3}{*}{$\begin{array}{l}\text { Virus } \\
\text { isola- } \\
\text { tion }\end{array}$} \\
\hline & & \multicolumn{6}{|c|}{ Serum dilution } & \multirow{2}{*}{$\left|\begin{array}{c}\text { Anti- } \\
\text { gen } \\
\text { control }\end{array}\right|$} & \multirow{2}{*}{$\begin{array}{l}\text { Anti- } \\
\text { body } \\
\text { titer }\end{array}$} & \multirow{2}{*}{$10^{-1}$} & \multirow{2}{*}{$10^{-2}$} & \\
\hline & & 2 & 4 & 8 & 16 & 32 & 64 & & & & & \\
\hline G 1 & - & 0 & 0 & 0 & 0 & & & 0 & & $0 ; 4$ & 0,5 & - \\
\hline G 2 & - & 0 & 0 & 0 & 0 & 0 & & 0 & & 0,5 & $0 / 3$ & - \\
\hline G 3 & - & 0 & 0 & 0 & 0 & & & 0 & & 0,3 & $0 / 4$ & - \\
\hline G 4 & - & 0 & 0 & 0 & 0 & 0 & 0 & 0 & & 0.4 & 0,5 & - \\
\hline G 5 & - & 0 & 0 & 0 & & & & 0 & $1: 32$ & $0 / 2$ & $0 / 4$ & - \\
\hline G 6 & - & 0 & 0 & 0 & 0 & 0 & & 0 & & $2 / 4^{*}$ & $1 / 4$ & + \\
\hline G 7 & - & 0 & 0 & 0 & 0 & & & 0 & & 0,5 & 0,5 & - \\
\hline G 8 & - & 0 & 0 & 0 & 0 & & & 0 & & 5,5 & $2 / 5$ & + \\
\hline G 9 & - & 0 & 0 & 0 & & & & 0 & & 0,4 & $0 / 5$ & - \\
\hline
\end{tabular}

- Virus inoculated: Street virus derived from the brain of rabid dog No. 163. (mouse brain of the 1st passage)

Virulence: $L^{2} D_{50}$ estimated by intracerebral inoculation of mice was 4.83 .

Inoculation: Guinea pigs were inoculated with $0.1 \mathrm{ml}$ of $10 \%$ mouse brain emulsion into the sole.

Guinea pigs inoculated showed no symptoms during the observation period of 3 weeks.

Those pigs were sacrificed by bleeding at the end of this period and their brain removed were examined.

Antigen for complement fixation test: $40 \%$ guinea pig brain emulsion.

Pathological examinations: For the detection of Negri body and non-purulent encepbalitic picture.

*2,4 indicates that 2 out of 4 mice injected died of rabies.

it is considered that at the first stage when rabies virus settled on the brain tissue, the animal still maintains quite normal appearance and it develops the rabic prodrome such as excitement, restlessness, etc. when the virus begins to multiplicate rapidly. By this time, there exists a considerable amount of the virus in the brain tissue and the antigen prepared from such materials has distinct antigenicity.

According to the informations received from our co-workers, Shimada and Kato, those cases which were negative in the detection of Negri body or nonpurulent encephalitic inflammation by pathological examinations and the isolation of virus was positive by intracerebral inoculation, were approximately $3 \%$. Whereas, within the limit of our experiment there was not even a case of complement fixation test negative and positive in the isolation of virus. Aside from the formation of Negri body, when the fact is taken into consideration that it requires a considerable length of time before the non-purulent encephalitic inflammation develops, there is a possibility that the case such as No. 26 (Table 7) might happen when the examination is done at an early 


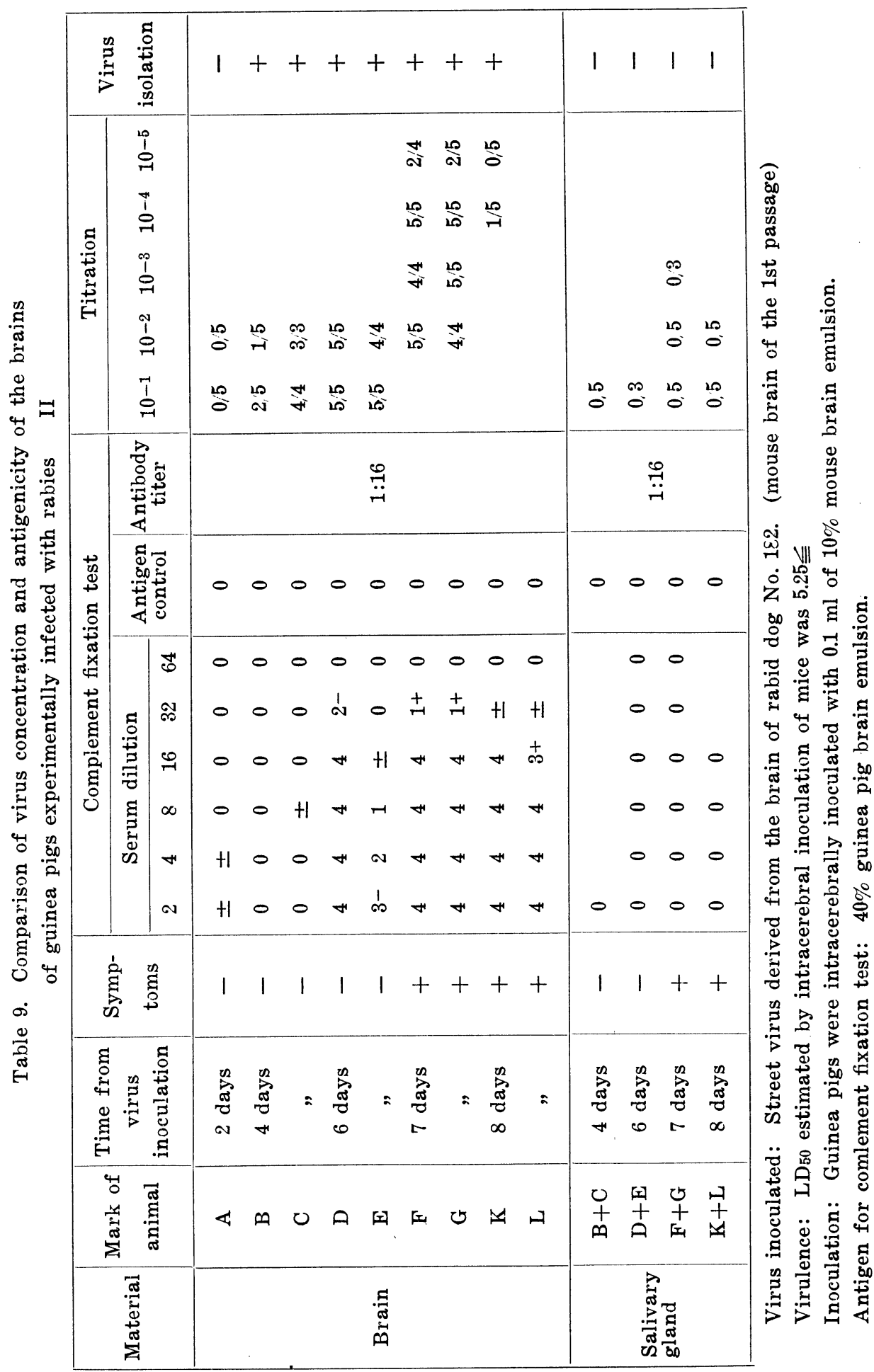


Table 10. Comparison of virus concentration and antigenicity of the brains of guinea pigs experimentally infected with rabies III

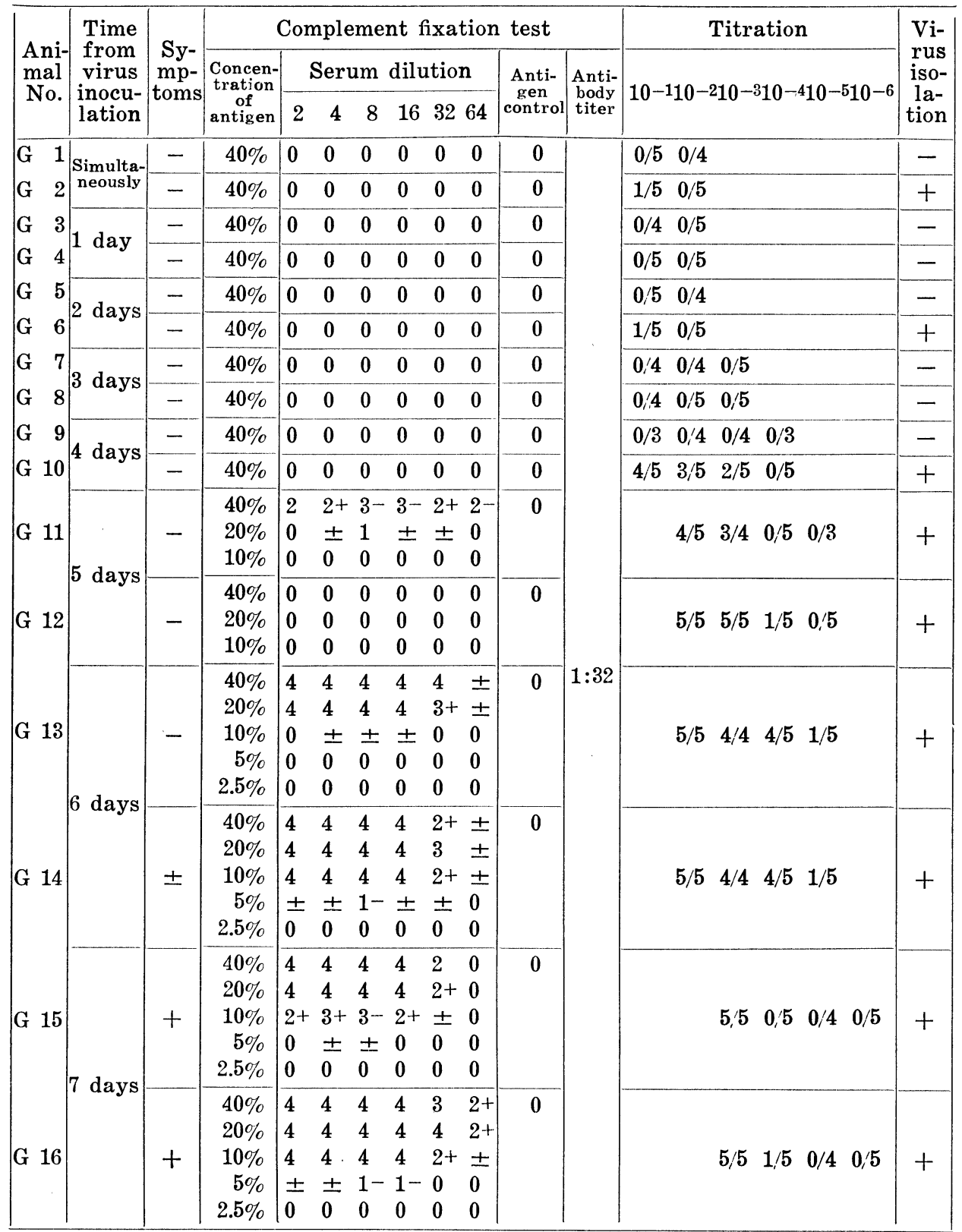

Virus inoculated: Street virus derived from the brain of rabid dog No. 182. (mouse brain of the 1st passage)

Virulence:

LD50 estimated by intracerebral inoculation of mice was 4.83 .

Inoculation: Guinea pigs were inoculated with $0.1 \mathrm{ml}$ of $10 \%$ mouse brain emulsion into the brain.

Antigen for complement fixation test: $40 \%$ guinea pig brain. 
period of the incubation. Therefore, it is intended to investigate the pathological pictures and the antigenicity of the antigen.

\section{Discussion}

As a laboratorial diagnostic measure for rabies, the complement fixation test, in which the brain and salivary gland antigen of suspicious animal and the immune serum prepared by immunizing guinea pigs with the fixed rabies virus and street virus were used, was carried out parallel to the ordinary pathological examinations, isolation of the virus and its immunological identification. Within the limit of our experiment which was done on 105 cases of animals suspected of rabies, the findings of complement fixation tests made with the brain of suspicious animals were in perfect accordance with the findings of the virus isolation except 3 cases in which the results of the complement fixation test were weak positive (Table 11). In addition to this, the complement fixation test made with the brains of 23 cases of normal stray dogs were all negative. It is believed, therefore, that all the positive reactions of our complement fixation test were the specific reactions produced by the street virus or some antigenic substances which were produced by its multiplication contained in the material examined.

While on the other hand, the detection of Negri body by stamp sample or section sample of Ammon's horn revealed lesser number of positive cases, which was quite inevitable in view of the facts that it requires a considerable length of time before Negri body is formed and also some strains of rabies

Table 11. Summarized findings of virus isolation, pathological examinations and complement fixation test made on the brains of

rabies suspected animals

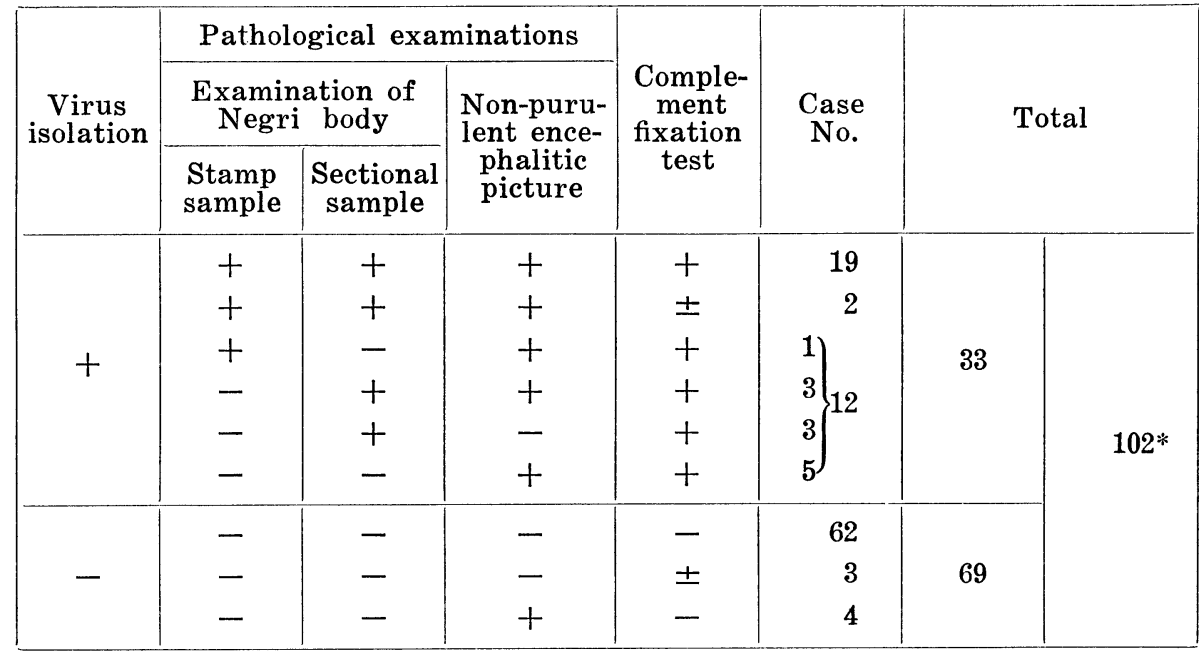

* Out of the total 105 cases tested, 3 cases (Nos. 10, 52, 105) were excluded from the table as their tests were not complete. 
virus failed to form it. Further, regarding the detection of non-purulent encephalitic inflammation, there were 4 cases which were positive out of 105 cases examined, but the findings of complement fixation test and the isolation of virus were negative. While exercising pathological examinations of rabies, the greatest trouble encountered with is the differentiation from the encephalitic type of distemper. The brain of this encephalitic type of distemper will present not merely an inclusion body which resembles very much to that of Negri body, but also will show so-called non-purulent encephalitic inflammation. Of course the secondary infection caused by Bac. bronchisepticus produced in the respiratory system can easily be differentiated by the pathological changes, however, sometimes the differentiation was quite impossible without the help of virus isolation using mice. But this differentiation is possible immunologically by the complement fixation test devised by us. The four cases of positive non-purulent encephalitic inflammation and negative complement fixation reaction and virus isolation were the cases of the encephalitic type of distemper (Table 11). Regarding those 3 cases of complement fixation reaction weak positive $( \pm)$ and virus isolation negative, the presence of virus should be suspected, as there was two cases in which the complement fixation reaction was ( \pm ) and the virus isolation was also positive. In addition, there was a case (Material No. 26) in which the virus isolation from the brain tissue was negative in spite of the positive finding of complement fixation test. However, the findings of both complement fixation reaction and virus isolation of the salivary gland were positive supporting the reliability of the above inference.

It is needless to say that the danger of rabies infection is much greater in the case in which the complement fixation test made with the salivary gland is positive than the case it is positive with the brain material. It can be said, therefore, that the present method of diagnosis is much more superior to those hitherto been used in the diagnosis of rabies on the point that it can give such a decisive diagnosis within a relatively short period of time.

But the findings of complement fixation test made with salivary gland, as shown in Table 12, were not of complete conformance. On the other hand, when the virulence of brain tissue was compared with that of salivary gland in each of the animals suspected of rabies, it was found to be equivalent or even higher on the salivary gland. Besides, considering the fact that all the cases in which the virus isolation from the brain tissue was positive were positive also in the virus isolation from the salivary gland, all the prophylactic treatment should be exercised being based on the findings of the complement fixation test made with the brain tissue regardless to the findings of the same test made with the salivary gland.

Further, some substance which is inhibitory to the complement fixation reaction was suspected to present in salivary gland lowering the titers of complement fixation tests made with salivary gland and mucin was suspected 
to play the role. The brain tissue of rabid dog, which had shown a positive complement fixation reaction, was prepared into 2 kinds of $40 \%$ emulsion. One was the usual emulsion and the other was the emulsion prepared by using $5 \%$ mucin solution. Using those two emulsions as antigen, complement fixation tests were carried out. The results of those tests are shown in Table 13 and it was proved that the mucin was inhibiting the complement fixation reaction. When the antigenicity of salivary gland is promoted, therefore, by some treatment which will eliminate the influence of mucin, the findings of complement fixation tests made with salivary gland will serve to give decisive diagnosis of rabies.

The time required for the diagnosis of rabies has a great importance in the treatment as well as in the prognosis of the injury. The quickest method hitherto been known is the stamp sample of Ammon's horn prepared by Sellers' or other staining method which is capable of giving diagnosis within 10 to 20 minutes if carried out by the trained technician. The method introduced in

Table 12. Comparison of the findings of virus isolation and complement fixation test made on the brains and salivary glands of

Animals suspected of rabies

\begin{tabular}{|c|c|c|c|c|c|c|}
\hline \multicolumn{2}{|c|}{ Brain } & \multicolumn{2}{|c|}{ Salivary gland } & \multirow{2}{*}{$\begin{array}{c}\text { Number } \\
\text { tested }\end{array}$} & \multirow{2}{*}{\multicolumn{2}{|c|}{ Total }} \\
\hline $\begin{array}{l}\text { Virus } \\
\text { isclation }\end{array}$ & $\begin{array}{l}\text { Complement } \\
\text { fixation test }\end{array}$ & $\begin{array}{l}\text { Virus } \\
\text { isolation }\end{array}$ & $\begin{array}{l}\text { Complement } \\
\text { fixation test }\end{array}$ & & & \\
\hline $\begin{array}{l}+ \\
+\end{array}$ & $\begin{array}{l}+ \\
\pm\end{array}$ & $\begin{array}{l}+ \\
+ \\
+ \\
+\end{array}$ & $\begin{array}{l}+ \\
\pm \\
- \\
+\end{array}$ & $\begin{array}{l}6 \\
3 \\
5 \\
1\end{array}$ & 15 & \\
\hline - & + & + & + & 1 & 1 & 00 \\
\hline- & $\begin{array}{l}- \\
\pm\end{array}$ & $\begin{array}{l}- \\
- \\
-\end{array}$ & $\begin{array}{l}- \\
\pm \\
\pm\end{array}$ & $\begin{array}{r}47 \\
2 \\
1\end{array}$ & 50 & \\
\hline
\end{tabular}

Table 13. Influence of mucin on complement fixation test

\begin{tabular}{|l|cccccc|c|}
\hline \multirow{2}{*}{ Antigen } & \multicolumn{5}{|c|}{ Serum dilution } & Antigen Control \\
\cline { 2 - 7 } & 2 & 4 & 8 & 16 & 32 & 64 & \\
\hline Saline antigen 1) & $2-$ & 1 & $1-$ & \pm & 0 & 0 & 0 \\
Mucin antigen 2) & \pm & \pm & & & & 0 \\
\hline Standard 3) & & 4 & 4 & $2-$ & $1-$ & 0 & 0 \\
\hline
\end{tabular}

1) $40 \%$ brain emulsion of rabid dog No. 52 emulsified with physiological saline.

2) $40 \%$ brain emulsion of the same dog emulsified with $5 \%$ gastric mucin solution.

Mucin used: Type 1701-W of Wilson Laboratories.

3) Brain emulsion of the mice infected with $\mathrm{MDH}$ strain. (4 units) 
the present study comes next and it requires approximately 5 hours from the time when the brain material is obtained to the time reading is made. Namely, approximately 1 hour is required in the elution of the antigen and 2 hours in the complement fixation reaction at a $37^{\circ} \mathrm{C}$ and the time required for the other manipurations is extremely small. As for the pathological examination, at least it is necessary to spend 48 hours in the preparation of the section samples and if done within 72 hours, it might be rather a quick work and if shorter, the staining of the samples may not be satisfactory. For the isolation of virus, if it is done by the intracerebral inoculation mice followed by neutralization test for identification, it requires at least 14 days and usually over 21 days. Thus, this method is rather a confirmatory test for the results obtained by other quick methods.

The immunological diagnosis of rabies was first attempted by Heller and Tomarkin(2) in the year 1907 and in the same year by Friedberger(3) independently. But unfortunately they found that their control antigens prepared from normal rabbit brain or normal dog brain fixed the complement and accordingly this diagnostic measure was abandoned. In 1910, Nedrigailoff and Sawtschenko(4) again took up this problem, however, as they used the antigen of low concentration $(20 \%)$ and carried out the complement fixation test at $37^{\circ} \mathrm{C}$ for 1 hour and moreover, as they did not pay special attention on the preparation and inactivation of the immune serum, inspite they obtained positive results in the complement fixation reaction in which the brain antigen of the rabbit infected with fixed virus was used, the complement fixation test made with the antigens prepared from the dog or human died of rabies was negative. They stated that sometimes the antigens prepared from the kidney, liver and spleen presented positive reaction. Lastly, they found that the antigens prepared from the salivary glands of 2 dogs and a man infected with street virus and died of rabies were positive in the complement fixation reaction and they insisted the availability of this reaction for the diagnosis of rabies. Later, in 1929, Kraus and Takaki(5) reported that "Kokto-antigen" which was prepared from the brain of the infected rabbit with fixed virus and heated at $100^{\circ} \mathrm{C}$ for 30 minutes, combines the complement. But their experiment was proved to be negative by the follow-up carried out by Marie and Urbain(6) in 1929. However, it is note worthy that the rabbit brain antigen of the fixed virus in the experiment performed by Marie and Urbain (6) combined approximately 5 times as much of the complement as that was combined by the control normal rabbit brain. In addition, in 1930, Kondo and Obana(8) reported that they failed to produce specific complement fixation reaction between boiled or glycerin treated antigens prepared from the brains of rabbits or dogs and the immune serum obtained from rabbits.

There are several other studies (12) on this immunological diagnostic measure, but they were the studies confined within the scope of laboratory and 
were not of those studies made on a relatively large number of animals suspected of rabies in the field.

Following are the reasons why our findings were different from those obtained in the above mentioned studies.

1. The difference in the concentration of the antigen used: We have engaged in the studies of various neurotropic viruses and while undertaking the experiments on the complement fixation test of Lansing type poliomyelitis virus (13), it was found necessary to use highly concentrated antigen as the propagation of this virus in the central nervous system is rather weak when compared with that of Japanese B encephalitis or St. Louis encephalitis viruses. Therefore, considering that the virus content in the brain of dog suspected of rabies is somewhat comparable to that of the mouse infected with Lansing type of poliomyelitis virus, or sometimes much smaller, the highest concentration of the brain emulsion which can be used as the antigen, namely, $40 \%$ was used.

2. In order to obtain the immune serum of the minimum anticomplementary activity, and which is free from any normal brain antibody, guinea pigs were used in place of rabbits and the immunization was done with the virus of the brain emulsion obtained from the homologous animal.

3. Normal guinea pig or horse serum which is free from the antibodies of neurotropic viruses was used as the medium for dilution of immune serum for the purpose of eliminating the non-specific reaction due to the normal dog brain antigen.

\section{CONCLUSIONS}

Employing the antigens prepared directly from the brain and the salivary gland of the animal suspected of rabies infection and the immune serum prepared by using both fixed and street viruses, the presence of certain antigenic substance specific to rabies virus or the propagation of the virus was proved by the complement fixation test.

The diagnostic value of this immunological diagnostic measure was compared with that of those pathological and virological methods hitherto used.

There was not even a case of virus isolation positive and the complement fixation test negative. However, there were 3 cases weak positive in the complement fixation test and virus isolation negative.

On the other hand, the test made with the antigen prepared from salivary gland was smaller in the number of positive cases than that made with the antigen prepared from the brain tissue and the reason for that was found to be due to the inhibitory influence of mucin present in the salivary gland. The virus was proved present in the salivary gland of the case in which the complement fixation test made with the brain antigen was positive and the virus isolation from the brain tissue was negative. In other words, the findings 
of complement fixation tests made with brain tissues agreed well with the findings of the virus isolation from salivary glands.

Not a case was negative in the complement fixation test among those cases which had been found Negri body positive. There were 5 cases of complement fixation test positive but Negri body negative.

In view of the above findings it is considered that the immunological diagnostic measure reported herein is superior to those laboratorial methods which have hitherto been used on the points that this can give decisive diagnosis within relatively short period of time.

\section{ACKNOWLEDGEMENT}

Brief explanation of this study was made at the meeting of the Virus Section of the Scientific Tests and Researches of the Ministry of Education.

The authors are greatly indebted to Mr. Ono of the Tokyo-To Central Dog Pound, who kindly supplied the materials used in the present study. This study was supported by the Grant for Scientific Tests and Researches of the Ministry of Education.

\section{REFERENCES}

(1) Webster, L. T. and Dawson, J. R.: Early diagnosis of rabies by mouse inoculation. Measurement of humoral immunity to rabies by mouse protection test. Proc. Soc. Exp. Biol. and Med., 32, 570-573, 1934.

(2) Heller, O. and Tomarkin, E.: Ist die Methode der Komplementbindung beim Nachweis spezifischer Stoffe für Hundswut und Vaccine brauchbar? Deutsch. med. Wschr., 33, 795-797, 1907.

(3) Friedberger, E.: Hat die Methode der Komplementablenkung eine Bedeutung für die Diagnose der Lyssa? Wien. klin. Wschr., 20, 879-880, 1907.

(4) Nedrigailoff, W. and Sawtscheko, W.: Über die Anwendung der Komplementbindungsmethode für die Diagnose der Tollwut. Zeitschr. Immunforsch., 8, 353-357, 1911.

(5) Kraus, R. and Takaki, J.: Der Nachweis der neurotropen Virusarten mittels Komplementablenkung mit Koktoantigen. Wien. klin. Wschr., 39, 624-625, 1926.

(6) Marie, A. C. and Urbain, A.: La reaction de fixation dans la rage. Compt. Rend. Soc. Biol., 101, 561-563, 1929.

(7) Kraus, R. and Michalka, J.: Die Diagnose des Lyssavirus mittels Komplementablenkung mit Koktoimmunogen und Glyzerinextrakt. II. Mitteilung. Zeitschr. Immunforsch., 47, 504--519, 1926.

(8) Kondo, S. and Obana, K.: On the complement fixation test of rabies. (in Japanese). Jueki Chosajo Research Report, No. 13, 287-297, 1930.

(9) Casals, J. and Palacios, R.: The complement fixation test in the diagnosis of virus infections of the central nervous system. J. Exp. Med., 74, 409-426, 1941.

(10) Casals, J., Olitsky, P. K. and Anslow, R. O.: A specific complement-fixation test for infection with poliomyelitis virus. J. Exp. Med., 94, 123-137, 1951. 
(11) Ando, K. et al.: Studies on the 1948 epidemic of Japanese B encephalitis in Tokyo area. 2nd report. Complement fixation tests performed on Japanese B encephalitis cases. (in Japanese). "Japanese B encephalitis" published by Committee of Researches on Japanese B encephalitis, 56-68, 1950.

(12) Kanazawa, K.: personal communication.

(13) Ando, K. and Ishii, K.: Complement fixation test using the antigen prepared from the nervous tissue of adult mice infected with poliomyelitis. Japanese Jour. Med. Sc. and Biol., in press. 